\title{
Aktualisasi Penguatan Pendidikan Karakter Peserta Didik melalui Kegiatan Pembelajaran
}

\author{
Hafizhatul Amanah ${ }^{1}$, Imron Arifin ${ }^{1}$, Sugeng Utaya ${ }^{2}$ \\ ${ }^{1}$ Manajemen Pendidikan-Universitas Negeri Malang \\ ${ }^{2}$ Pendidikan Geografi-Universitas Negeri Malang
}

\begin{tabular}{l}
\hline INFO ARTIKEL \\
\hline Riwayat Artikel: \\
Diterima: $15-08-2019$ \\
Disetujui: $20-20-2020$ \\
\hline
\end{tabular}

\section{Kata kunci:}

actualization;

strengthening character education;

learners;

aktualisasi;

penguatan pendidikan karakter;

peserta didik

\begin{abstract}
The purpose of the study was to determine the process of actualization PPK's (strengthening character education) program that using by MTs Khadijah and SMPN 2 Malang. The study used qualitative data by the sources were the principal, public relation, student center, and counseling. The technique used to check the validity of data include a process of credibility, dependability and conformability, and the data analysis was performed by collecting, condensation, display and drawing conclusion. The actualization process is carried out thorough the planning, implementation and controlling process. (1) planning is carried out after there is a submission about the activity by considering the character's value, making a schedule, establishing the person in charge and evaluation schedule. (2) PPK's program is actualized through intracurricular, co-curricular and extracurricular activities, (3) controlling are carried out directly and not as an example of monitoring in CCTV.
\end{abstract}

ABSTRAK

\begin{abstract}
Abstrak: Tujuan penelitian ini untuk mengetahui proses pengaktulisasian PPK peserta didik di MTs Khadijah dan SMPN 2 Malang. Penelitian menggunakan pendekatan kualitatif dengan sumber data yaitu kepala sekolah, humas, kesiswaan dan BK. Pengumpulan data dilakukan dengan wawancara, observasi dan dokumentasi. Pengecekan keabasahan data melalui proses kredibilitas, dependabilitas dan konformabilitas. Analisis data dilakukan dengan pengumpulan, pengembunan, penyajian data dan penarikan kesimpulan. Proses aktualisasi dilakukan melalui proses perencanaan, pelaksanaan dan pengontrolan. (1) perencanaan dilakukan setelah adanya usulan yang mempertimbangkan nilai-nilai karakter, pembuatan jadwal, pembentukan penanggungjawab dan jadwal evaluasi kegiatan. (2) PPK diaktualisasikan melalui kegiatan intrakurikuler, kokurikuler dan ekstrakurikuler, (3) pengontrolan kegiatan dilakukan secara langsung dan tidak seperti contoh pemantauan melalui CCTV.
\end{abstract}

\author{
Alamat Korespondensi: \\ Hafizhatul Amanah \\ Manajemen Pendidikan \\ Universitas Negeri Malang \\ Jalan Semarang 5 Malang \\ E-mail: hafizhatulamanah95@gmail.com
}

Peserta didik atau sebutan lainnya yang digunakan dalam dunia pendidikan (Imron A., Maisyaroh., 2003) merupakan subjek utama dalam pelaksanaan pembelajaran yang melibatkan guru sebagai pendidik (Nasihin \& Sururi, 2011) dengan tugas utama adalah mendidik, mengajar dan mengarahkan. Proses mendidik tidak hanya melalui pemberian ilmu pengetahuan, tetapi juga dengan pembentukan karakter positif untuk menunjang hasil belajar yang baik sehingga mampu menghasilkan output yang tepat sasaran (Sonhadji \& Huda, 2015). Karakter merupakan pembeda antar manusia baik oleh sifat, sikap, dan perilaku perbedaan ini muncul dalam setiap aktivitas termasuk mengenai kebutuhan dana berbagai bidang (Imron, 2015), contoh lain adalah pada saat pengambilan keputusan, pernyataan ini sejalan dengan teori yang dipaparkan oleh (Suyadi, 2018) bahwa dalam definisinya secara etimologi, karakter berasal dari bahasa Yunani yaitu ehrassein yang bermakna sebagai penanda dan menggoreskan.

Karakter dikelompokkan menjadi dua yaitu positif dan negatif, (Dahliyana, 2017) menyebutkan bahwa karakter negatif meliputi kasus pembulian, pencurian, penyalahgunaan narkoba dan lain sebagainya, sementara (Dalyono \& Lestariningsih, 2017) menggambarkan karakter negatif sebagai tindakan yang dapat merugikan orang lain bahkan sampai menghilangkan nyawa, subjek yang melakukan tindakan ini memperlihatkan peran antagonis (Krakowiak \& Tsay-Vogel, 2013). Peran antagonis tersebut kemudian dijabarkan oleh Chusnani, (2013) secara global yaitu berbohong dalam setiap pekerjaan yang dilakukannya, korupsi, nepotisme, terus memperlihatkan sikap kurang sabar dalam mengahadapi berbagai persoalan, tidak mempunyai rasa malu, kurang menghargai prestasinya sendiri, tidak memiliki sopan dan santun kepada orang lain dan sering melanggar peraturan. Sedangkan mengenai tindak antagonis yang sering dilakukan oleh peserta didik dalam lembaga pendidikan adalah penyalahgunaan narkoba, minuman keras, seks bebas, jual beli barang haram, tawuran, bullying (mengganggu kenyamanan belajar temannya), mencopet, menipu, berbohong kepada kedua orangtua mengenai peraturan sekolah dan yang sampai saat ini 
menjadi budaya adalah mencontek (Agung, 2018), sedangkan karakter negatif yang digambarkan oleh (Sobri, 2019) yang sering dilakukan dalam lingkungan pendidikan dan membudaya ialah mencontek. Berdasarkan pada beberapa pernyataan tersebut maka dapat disimpulkan bahwa karakter negatif merupakan perilaku yang dapat dianggap sebagai tindak kejahatan oleh peserta didik, tergantung pada tingkat kejahatan yang dilakukan (Sumarni, Dardiri, \& Zuchdi, 2015).

Karakter positif digambarkan dalam PP RI Nomor 87 Tahun 2017 tentang PPK seperti religius, mandiri, nasionalis, gotongroyong dan integritas yang kemudian terbagi ke dalam delapan belas karakter. Berikut peneliti memperjelas mengenai karakter positif peserta didik, antara lain (1) menjadi hamba yang patuh pada printah dan larangan penciptanya, (2) menjadi disiplin dalam berabagi aktivitas seperti hadir tepat waktu, pulang tepat waktu, mengerjakan tugas tepat waktu dan hal lain sehingga tidak mengganggu aktivitas berikutnya, (3) mempunyai tanggungjawab yang besar atas berbagai amanah yang diberikan kepadanya, sehingga karakter integritasnya muncul dan dapat dipercaya oleh orang lain, (4) memiliki sikap sopan dan santun kepada orang yang lebih tua darinya, (5) peduli pada semua orang tanpa mengenal agama, suku, ras, jabatan, kekayaan, dan lain sebagainya kemudian hal ini disebut sebagai pembentukan karakter toleransi, (6) memiliki sikap komunikatif sehingga mampu memunculkan kerjasama dan kerja keras untuk mencapai tujuan yang telah ditetapkan, (7) mampu bersikap adil baik dalam mengambil keputusan maupun tindakan sehingga tidak merugikan pihak manapun, (8) memiliki sikap rendah hati dan suka membantu, dan (9) cinta perdamaian dengan kata lain tidak akan pernah melakukan tindak kekerasan dalam bentuk apapun.

Karakter-karakter di atas dapat dipengaruhi oleh beberapa faktor, seperti lingkungan sosialnya, ekonomi, dan keluarga (Suparno, 2018), semua faktor ini secara pasif dapat menjadi penyebab karakter seseorang menjadi baik atau buruk, oleh karenanya manusia butuh untuk mengelola dirinya sendiri. Melalui faktor-faktor di atas kemudian dapat memunculkan tindakan sebagai aktivitas yang lahir dari pengaruh yang dialami langsung oleh manusia, tindakan inilah oleh (Berkowitz \& Bier, 2004) sebagai karakter yang digerakkan melalui hasil dari pikiran manusia sesuai dengan moral yang berlaku, teori ini kemudian diperkuat kembali dengan pernyataan oleh (Mustoip, Japar, \& Zulela, 2018) bahwa segala sesuatu yang dihasilkan dan diperlihatkan oleh manusia merupakan karakter manusia tersebut, dengan kata lain apabila tindakan yang baik maka karakter yang ditunjukkanpun akan baik dan sebaliknya. Berdasarkan pada pernyataan di atas maka dapat disimpulkan bahwa karakter dapat membentuk pola perilaku seorang manusia, oleh karena itu baik buruknya perilaku yang dibentuk merupakan hasil dari pemikirannya (Sudrajat, 2011).

Indonesia merupakan negara yang memiliki moral dan menjunjung tinggi nilai tersebut sehingga membentuk kesadaran dan kepedulian antar sesama (Mulyasa, 2016), namun permasalahan moral tersebut saat ini menjadi topik hangat untuk dibicarakan, melalui hal ini terbentuklah kebijakan pendidikan yang memusatkan perhatian pada pembentukan karakter peserta didik. Membentuk karakter positif ke dalam diri seseorang tidak mudah, perlu untuk menanamkan terlebih dahulu rasa percaya diri yang tinggi (Judiani, 2010), namun pada kenyataanya seperti yang dijelaskan oleh Daniel Goleman dalam bukunya berjudul multiple intelligence (kemampuan ganda) mengungkapkan mengenai kebijakan pendidikan yang seharusnya meletakkan $80 \%$ untuk pengembangan emosional dan sosial, sedangkan 20\% sisanya adalah untuk aspek intelektual (Maksudin, 2013).

Sebagai usaha untuk meminimalisir perkembangan karakter peserta didik, saat ini Indonesia sudah merancang kebijakan baru yang diadopsi dari kebijakan lama, yaitu pendidikan karakter dengan target pencapaian pelaksanaanya dapat dikatakan berhasil apabila mampu menanamkan nilai-nilai karakter peserta didik dan merealisasikannya dalam kehidupan (Fajarini, 2014). Bukan hanya Indonesia yang memperhatikan permasalahan karakter namun juga negara maju lainnya seperti Amerika, hal ini terlihat dari pengakuan (Watz, 2011) yang mengutip pernyataan Presiden George W. Bush mengenai dana yang dikeluarkan untuk mengadakan pendidikan dan pembentukan karakter. Namun perkembangan karakter harus terus dikuatkan untuk dapat bermanfaat bagi kehidupan yang berlanjut, oleh sebab itu Menteri Pendidikan membentuk program baru yaitu PPK (Penguatan Pendidikan Karakter).

PPK (penguatan pendidikan karakter) dalam pedomannya disebutkan sebagai upaya menguatkan karakter-karakter yang sudah terbentuk melalui pembelajaran pendidikan karakter, penguatan dapat dilakukan dalam berbagai kegiatan seperti intrakurikuler, kokurikuler dan ekstrakurikuler. Penguatan karakter melalui kegiatan intrakurikuler dilakukan dengan mengintegrasikan nilai-nilai karakter ke dalam materi pembelajaran di dalam kelas, selain itu atas wewenang sekolah pun bisa merancang kegiatan pembelajaran lainnya dalam kelas untuk memperkuat nilai-nilai karakter yang dimaksud sebagai bagian dari proses pembelajaran. Sedangkan penguatan karakter melalui kegiatan kokurikuler adalah dengan menciptakan pendalaman dan pengayaan mengenai pengetahuan yang diperoleh melalui kegiatan intrakurikuler, kokurikuler dapat bersifat pengembangan akademik maupun non akademik, terakhir adalah penguatan melalui kegiatan ekstrakurikuler baik dibidang religius keagamaan, olahraga maupun pengembangan minat dan bakat lainnya. Penguatan melalui kegiatan-kegiatan di atas dapat dilakukan dengan pembiasaan dan percontohan langsung dari guru maupun masyarakat di dalam lingkungan sekolah sehingga perwujuduan tertanamnya karakter positif yang kuat dapat diaktualisasikan oleh sekolah melalui kegiatan-kegiatan yang disebutkan di atas.

\section{METODE}

Penelitian ini menggunakan jenis pendekatan kualitatif yang bertujuan untuk mendeskripsikan dengan jelas mengenai fenomena aktualisasi perwujudan PPK yang dilakukan di MTs Khadijah dan SMPN 2 Malang. Menurut (Suharsimi, 2013) pendekatan kualitatif difokuskan untuk menganalisi suatu kondisi, tempat, fenomena, peristiwa atau kegiatan-kegiatan yang dilakukan di tempat penelitian. Analisis data dalam penelitian ini dilakukan dengan analisis lintas kasus, analisis ini oleh (Bogdan \& Bikien, 1998) disebut sebagai analisis yang digunakan untuk mengamati fenomena yang terjadi di dua latar 
belakang yang berbeda, dan hal ini ditemukan dari latar belakang kedua sekolah yaitu MTs yang berlandaskan agama dan SMPN 2 Malang yang merupakan sekolah umum (Ulfatin, 2015) juga menyebutkan bahwa dengan menggunakan penelitian dengan analisis lintas kasus, maka peneliti akan menemukan perbandingan dalam pelaksanaan pengaktualisasian perwujudan PPK oleh kedua sekolah.

Kehadiran peneliti tentu sebagai intrumen utama untuk memperoleh data, karena penelitilah yang mengetahui dengan jelas tujuan dan latar belakang penelitian (Creswell, 2016), penelitian dilakukan di MTs Khadijah Malang dan SMPN 2 Malang dengan sumber data yaitu kepala sekolah, humas, kesiswaan dan guru BK. Teknik pengumpulan data menggunakan wawancara, observasi, dan dokumentasi karena dalam penelitian kualitatif yang umum digunakan adalah melalui ketiga aspek tersebut (Creswell, 2016). Analisis data lintas kasus ini dapat digambarkan sebagaimana gambar 1.

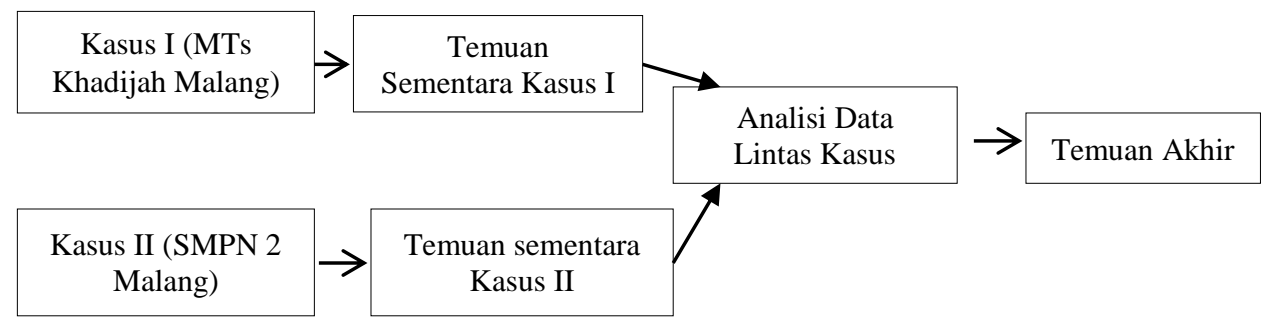

Gambar 1. Proses Analisis Data Lintas Kasus

Pengecekan keabsahan temuan data dilakukan dengan menggunakan tehnik pengecekan validitas internal, validitas eksternal, reliabilitas, dan objektivitas (Moleong, 2016). Tahap-tahap penelitian dilakukan dengan memulainya dari tahap persiapan seperti membuat pertanyaan, jenis data yang diinginkan dan kesiapan peneliti secara fisik atau pembuatan laporan izin penelitian, kemudian tahap pelaksanaan dimana peneliti mulai melakukan pengamatan di sekolah, dan terakhir adalah tahap penyusunan laporan.

\section{HASIL}

Hasil penelitian ini menjawab permasalahan melalui analisis kasus individu dari masing-masing kasus yaitu kasus I (MTs Khadijah Malang) dan Kasus II (SMPN 2 Malang) untuk selanjutnya menemukan hasil akhir dari analisis lintas kasus.

\section{Temuan Penelitian Kasus Individu}

Berdasarkan hasil temuan penelitian pada kasus I mengenai bentuk aktualisasi penguatan pendidikan karakter melalui kegiatan pembelajaran di MTs Khadijah Malang diperoleh hasil bahwa upaya penguatan karakter diaktualisasikan dalam berbagai kegiatan yang melibatkan peserta didik dan guru. Pengaktualisasiannya terstruktur dengan baik, dimulai dengan proses perencanaan yang optimal sampai pada pengontrolan oleh kepala sekolah untuk melihat perkembangan pelaksanaan kegiatan. Perencanaan kegiatan penguatan dilakukan dengan adanya usulan terlebih dahulu oleh para guru, usulan mengenai kegiatan harus mempertimbangkan keberadaan nilai-nilai karakter yang akan dibentuk dan diperkuat, kemudian pihak sekolah mendiskusikan bersama untuk memperoleh kegiatan yang tepat agar pembentukan karakter dapat terwujud dengan baik. Tahap selanjutnya adalah membentuk penanggung jawab untuk pelaksanaan kegiatan penguatan, serta bekerjasama dengan tim pengembang dari pihak eksternal untuk kelancaran kegiatan, setelah itu dibuat jadwal kegiatan oleh masing-masing penanggungjawab dan disepakati oleh kepala sekolah dan semua pihak yang terlibat dalam perencanaan.

Contoh yang diperlihatkan dalam proses perencanaan pengadaan adalah ketika MTs Khadijah Malang ingin memperkuat karakter nasionalis, sedangkan pada kenyataanya untuk dua tahun terakhir ini Madrasah tidak melaksanakan upacara dikarenakan masalah tempat dan pemberian kesempatan untuk MI Khadijah yang masih dalam yayasan yang sama untuk mengenal bagaimana proses upacara yang baik. Oleh karena itu, Madrasah mengadakan kegiatan apel pagi pada Selasa pagi yang dalam pelaksanaanya nanti tidak jauh berbeda dengan upacara, sehingga nilai-nilai nasionalis seperti menyanyikan lagu kebangsaan dan lain sebagainya tetap dilaksanakan. Selanjutnya kegiatan mengaktualisasikan penguatan karakter yang telah direncanakan sebelumnya ke dalam berbagai aktivitas pembelajaran di Madrasah. Berdasarkan hasil wawancara dengan keempat sumber data, diperoleh hasil temuan bahwa pengaktualisasian PPK ini dilakukan dalam semua kegiatan yang melibatkan peserta didik, baik dalam ranah intrakurikuler, kokurikuler, maupun ekstrakurikuler.

Pengaktualisasian PPK dalam kegiatan intrakurikuler dilakukan dengan mengintegrasikan nilai-nilai karakter ke dalam pembelajaran oleh guru, hal tersebut dapat dilihat dalam RPP yang dirancang untuk proses pembelajaran, sehingga nampak upaya dan tindakan guru dalam memperkuat karakter peserta didik. Kegiatan penguatan melalui intrakurikuler tidak hanya dalam proses KBM (kegiatan belajar mengajar) namun juga teraktualisasikan ke dalam kegiatan pra KBM seperti membaca do'a dan mengaji bersama-sama, dan sholat dhuha pada waktunya (pagi hari) yang kemudian kegiatan ini diinternalisasikan sebagai kegiatan intrakurikuler karena masuk ke dalam mata pelajaran, selanjutnya mengenai contoh yang digambarkan oleh 
kepala madrasah tentang pelaksanaan PPK dalam kegiatan intrakurikuler pada pembelajaran PKn, maka oleh guru akan memperkenalkan sejarah Indonesia, lagu-lagu kebangsaan, nama-nama pahlawan dan sejarahnya dan melalui penerapannya madrasah mengharapkan penguatan untuk karakter nasionalis seperti cinta tanah air, cinta damai, dan rasa ingin tahunya meningkat, kemudian untuk penguatan karakter toleransi maka diperoleh melalui pembelajaran agama, untuk pelaksanaan kegiatan intrakurikuler dilakukan mulai pukul 07.00-14.00.

Penguatan pendidikan karakter yang dilakukan pada kegiatan kokurikuler adalah berupa pengayaan dan pendalaman pemahaman peserta didik baik tentang pengetahuan keagamaan maupun akademik. Karena latar belakang sekolah yaitu Madrasah sehingga kegiatan kokurikuler yang diperbanyak adalah pada pendalaman pengetahuan tentang agama Islam, seperti pada kegiatan kultum pagi, kegiatan ini dilakukan secara bergantian oleh peserta didik dengan memberikan sebuah materi ceramah untuk waktu yang singkat di depan teman-temannya, kegiatan ini diharapkan mampu menguatkan karakter religius peserta didik dan juga percaya diri, mandiri, bertanggungjawab atas amanah yang diberikan dan integritas, untuk kegiatan religius selalu diprioritaskan oleh Madrasah sehingga tiap tahunnya selalu ada upaya peningkatan dan perwujudan kegiatan keagamaan lainnya seperti kegiatan kultum yang baru berumur enam bulan atau baru diterapkan pada semester akhir tahun ajaran baru, kokurikuler dibidang agama lainnya adalah manasik haji yaitu untuk memperkuat pengetahuan peserta didik mengenai pelaksanaan haji yang baik dan benar yang sebelumnya diperoleh melalui pembelajaran agama. Sedangkan untuk kegiatan kokurikuler dibidang akademik adalah literasi yaitu untuk memperkuat karakter gemar membaca dan rasa ingin tahu yang besar tentang ilmu pengetahuan, pengadaan untuk kokurikuler akademik selalu atas dasar adanya peraturan atau mempertimbangkan keberhasilan kegiatan tersebut untuk kemudian dilaksanakan namun bukan berarti Madrasah tidak memperhatikan IPTEK peserta didik, kegiatan kokurikuler ini dilakukan setelah KBM berakhir pada hari Senin-Kamis.

Aktualisasi penguatan pendidikan karakter terakhir dilakukan dalam kegiatan ekstrakurikuler, dimana bentuk kegiatan yang dilakukanpun tidak hanya dibidang olahraga, atau pengembangan minat dan bakat lainnya namun juga tetap menitikberatkan pada kegiatan yang bernuansa religi sehingga peserta didik dalam setiap aktifitasnya harus melibatkan Allah Swt sebagai pencipta yang selalu mengawasi perbuatan manusia. Ekstrakurikuler yang diadakan di MTs Khadijah Malang antara lain tilawah, hafidz qur'an, tahfidz al-qur'an, nasyid, muhadharoh, KIR (karya ilmiah remaja), desain grafis, olimpiade IPA, matematika, dan bahasa Inggris, tapak suci, tata boga, paskibra, pramuka, futsal, basket, voly dan bulutangkis. Karakterkarakter yang diperkuat melalui kegiatan ekstrakurikuler adalah gotongroyong, kerja keras, integritas dalam kegiatan pramuka yang juga mengajarkan kemandirian dan kedisiplinan, jujur, bertanggungjawab, dan menghargai prestasi, untuk pelaksanaanya kegiatan ekstrakurikuler dilakukan pada hari Jum'at setelah proses KBM berakhir sampai pukul 17.30 yaitu untuk kegiatan pramuka, namun ada beberapa ekstrakurikuler dibidang olahraga yang dilakukan pada hari Rabu setelah proses KBM tentunya.

Selain itu proses penguatan pendidikan yang dilakukan oleh MTs Khadijah Malang ini adalah dengan membiasakan peserta didik untuk menampakkan perilaku yang baik, oleh karenanya Madrasah juga menekankan pada semua guru untuk memberikan perilaku yang baik saat bertemu dengan peserta didik, sehingga guru secara tidak langsung dapat memberikan contoh yang baik dalam menjalankan aktifitas kehidupannya. Penguatan juga dilakukan dalam aktifitas penerapan program "panca S" yaitu sapa, salam, senyum, sopan, santun dan salim saat peserta didik memasuki gerbang sekolah dan ketika bertemu dengan guru atau orang yang lebih tua saat di lingkungan masyarakat. Pertimbangan penting yang perlu diperhatikan dalam pelaksanaan PPK oleh MTs Khadijah adalah tetap memperhatikan peraturan dan tata cara bergaul dan berinteraksi sesuai syariat Islam, seperti contoh pemisahan antara laki-laki dan perempuan dalam kegiatan tertentu, namun apabila terpaksa untuk digabungkan maka akan dilakukan namun dalam pengawasan guru tentunya, sehingga tidak terjadi hal-hal yang kurang mengenakkan sehingga tampak perilaku semena-mena terhadap lawan jenis.

Pada kegiatan pengontrolan pelaksanaan kegiatan, kepala Madrasah bekerjasama dengan tim pengembang yang juga ada beberapa dari pihak luar, serta guru pembina kegiatan untuk kemudian mendiskusikan hasil kegiatan yang dilakukan, baik secara langsung maupun melalui penilaian masing-masing pihak. Selain itu Madrasah juga memasang beberapa CCTV pada ruangan yang memang sering dikunjungi oleh peserta didik, sehingga dalam waktu sekali dalam seminggu diperlihatkan kembali CCTV itu pada peserta didik yang bersangkutan, selain memasang CCTV, Madrasah juga menerapkan buku tatib untuk merekam perkembangan karakter peserta didik, apabila terlalu banyak melakukan pelanggaran, maka akan dikenakan sanksi sesuai dengan jenis pelanggaran yang dilakukan. Pengontrolan dilakukan dengan mengamati secara langsung kegiatan, namun apabila kepala sekolah sedang memiliki tanggungjawab lainnya maka pengontrolan dilakukan secara tidak langsung yaitu proses diskusi seperti yang dijelaskan di atas termasuk pada keterangan yang ditulis dalam buku tatib dan seringnya peserta didik tersebut diberikan layanan oleh guru BK untuk tidak mengulangi perbuatannya yang mana guru BK akan merekam kegiatan tersebut sebagai penilaiannya.

Bentuk pengaktualisasian PPK juga dilakukan oleh SMPN 2 Malang juga memiliki persamaan dan berbedaan, dan berdasarkan hasil temuan diperoleh bahwa PPK di sekolah ini dijalankan sesuai dengan pedoman dan peraturan yang diedarkan di sekolah yaitu melalui perencanaan yang baik, pelaksanaan dan pengontrolan. Perencanaan pengadaan PPK oleh SMPN 2 Malang dilakukan secara terstruktur dan melibatkan semua masyarakat sekolah dalam memberikan usulan, usulan yang diberikan juga berdasarkan pada nilai karakter yang ingin dibentuk dan diperkuat melalui kegiatan yang nantinya akan diadakan. Setelah usulan diterima dan disetujui oleh semua pihak selanjutnya dibentuk penanggungjawab kegiatan dan tim PPK yang terdiri dari coordinator dan wakil koordinator PPK, selanjutnya disusun kegiatan-kegiatan dengan mempertimbangan nilai karakter dalam usulan sebelum dan dibuat jadwal pelaksanaanya. Terakhir adalah perencanaan kegiatan perbaikan oleh 
koordinator PPK melalui proses merevisi kegiatan, proses ini dilakukan dua minggu sebelum tahun ajaran baru dimulai, sehingga dalam pelaksanaan berikutnya permasalahan yang sebelumnya ditemukan dapat diminimalisir, sebelumnya dijelaskan oleh kepala sekolah bahwa setelah jenis kegiatan diperoleh maka akan diberitahu kepada orangtua peserta didik melalui kehadiran mereka yang diundang langsung oleh sekolah, pertimbangan lainnya dalam mengadakan kegiatan adalah pengadaan sarana prasarana yang kemudian akan dirancang dalam RKA sarpras PPK.

Hasil perencanaan kemudian diaktualisasikan ke dalam berbagai aktivitas di sekolah dan sesuai dengan pedoman penyelenggaran PPK pada PP RI No.87 Tahun 2017 tentang PPK bahwa kegiatan PPK dapat dilakukan dalam kegiatan intrakurikuler, kurikuler, dan ekstrakurikuler ketiga kegiatan tersebut diaplikasikan oleh SMPN 2 Malang. Selain itu, ada kegiatan lain yang dirancang khusus sebagai penguat ketiga kegiatan tersebut. Pengaktualisasian PPK dalam kegiatan intrakurikuler adalah dengan mengintegrasikan nilai-nilai karakter ke dalam pembelajaran yang kemudian sebelumnya dirancang oleh guru dalam pembuatan RPP, selain itu sekolah juga mengupayakan berbagai kegiatan wajib yang dilakukan dalam kelas sebelum KBM dimulai yaitu berdo'a sesuai agama masing-masing (karakter religius/toleransi), melaksanakan program "semut (sejenak memungut sampah)" yang terlihat di samping kanan dan kiri bangku peserta didik (karakter cinta lingkungan), dan mengungkapkan kebaikan yang sudah dilakukannya pagi tadi terutama pada orangtuanya di rumah, setelah tiga kegiatan ini diselesaikan baru KBM dimulai.

Pelaksanaan PPK pada kegiatan kokurikuler sangat banyak terutama dibidang penguatan pemahaman ilmu pengetahuan akademik, namun tidak mengesampingkan penguatan pada bidang keagamaan, kegiatan kokurikuler yang dilakukan oleh SMPN 2 Malang antara lain pengadaan rumah kompas yaitu pengelolaan sampah berupa daun kering oleh peserta didik dan guru IPA untuk kemudian menjadikannya pupuk agar dapat digunakan untuk tanaman lainnya, arena area madutokek yaitu penanaman sejumlah tanaman toga atau bumbu dapur seperti kunyit, jahe dan lain sebagainya, kemudian ada budi daya rumah jamur dan ketiga kegiatan ini merupakan pengintegrasian pembelajaran IPA karena guru IPA terlibat dalam pengelolaannya. Kokurikuler lainnya adalah jum'at kitab dan untuk peserta didik non muslim diadakan kegiatan pembinaan rohani, tutor sebaga untuk lebih memahamkan peserta didik mengenai tata cara sholat yang baik oleh temannya sendiri dan kokurikulur religius terjadwal yaitu pada hai Senin-Selasa berupa pembelajaran tambahan materi fiqih dan awidah akhlak, pesantren kilat atau pondok ramadhan, semuanya dilakukan untuk memperkuat karakter religius. Untuk penguatan karakter pada kegiatan kokurikuler bidang akademik adalah pada kegiatan literasi, aktifitas wajib semua peserta didik di pagi hari sebelum KBM dimulai yaitu menyanyikan lagu kebangsaan dan asmaul husna secara serentak, mengadakan kegiatan 17 agutusan, perayaan hari pahlawan, pengadaan hari kartini dan lain sebagainya. Sedangkan pelaksanaan PPK pada kegiatan ekstrakurikuler antara lain dikelompokkan ke dalam bidang olahraga meliputi futsal, voly, basket, tenis meja, catur, karate, pramukan dan dewan galang, kemudian dalam pengembangan minat dan bakat antara lain jurnalistik, PMR, tari dan ansambel musik, terakhir pada bidang keagamaan meliputi hadrah, tartil dan karawitan. Semua kegiatan yang mengaktualisasikan penguatan pendidikan karakter yang dilakukan di SMPN 2 Malang adalah dengan pembiasaan sehingga terbentuk perilaku peserta didik yang didominasi oleh karakter positif.

Kegiatan pengontrolan dilakukan dengan memasang 64 CCTV pada semua sudut di sekolah, hal ini dilakukan untuk memantau perilaku peserta didik yang tidak bisa dijangkau, pembuatan loker laporan yang mana semua pihak yang melihat adanya pelanggaran dapat melaporkannya dan memasukan identitas peserta didik ke dalam loker yang sesuai dengan kelasnya. Pengaaan BKS (buku kepribadian siswa) yang dijalankan oleh guru BK beserta layanan-layanannya untuk memperkuat karakter peserta didik yang sering melakukan pelanggaran, dan selanjutnya adalah kreatifitas atas keinginan kepala sekolah sendiri dalam membuat buku rekapitulasi perkembangan peserta didik, dalam buku rekap tersebut berisi nama peserta didik, kelas dan pelanggaran yang sering dilakukan dan buku ini dapat dijadikan bukti apabila orangtua ingin melihat perkembangan dan aktifitas anaknya di sekolah. Pengadaan sarana prasarana ini sehingga terlihat lengkap adalah karena adanya perencanaan yang dirangkum dalam RKA PPK tentang kebutuhan sarana prasarana yang kemudian menjadi tanggungjawab koordinator PPK untuk mendatangkannya dan tentu pihak sekolah juga bekerjasama dengan stakeholders dan dinas pendidikan, karena tujuan pengadaannya adalah untuk mempermudah pelaksanaan program PPK. 
Temuan Penelitian Lintas Kasus

\section{Manajemen Penguatan Pendidikan Karakter Peserta Didik}

\section{Perencanaan}

Perencanaan kegiatan PPK melibatkan semua pihak internal. Masyarakat (orangtua) tetap diberi kesempatan untuk memberikan masukan mengenai kegiatan program yang direncanakan. Harus ada pihak yang mengusulkan terlebih dahulu sebelum diadakan perencanaan. Usulan harus berdsarkan kebutuhan peserta didik dan mempertimbangkan faktor seperti lingkungan dan ekonomi peserta didik maupun sekolah. Selain itu usulan yang diberikan harus disertakan dengan karakter yang ingin dicapai atau diperkuat melalui kegiatan yang nantinya diadakan. Mengidentifikasi kebutuhan kegiatan program oleh MTs Khadijah Malang adalah dengan memanfaatkan fasilitas disekitar sekolah, sedangkan SMPN 2 Kota Malang membuat RKA PPK tentang sarana prasarana. Setelah disepakati oleh kepala sekolah, maka akan dibuat jadwal pelaksanaan dan membentuk penanggungjawab kegiatan. Mengadakan jadwal merevisi kembali kegiatan apabila dibutuhkan.

\section{Pelaksanaan}

PPK dilaksanakan pada semua kegiatan yang melibatkan peserta didik di sekolah. PPK dilakukan pada kegiatan intrakurikuler, kokurikuler dan ekstrakurikuler. PPK ada yang terjadwal dan tidak. Bekerjasama dengan pihak luar dalam melaksanakan kegiatan kokurikuler bidang keagamaan (religius). Kokurikuler juga dilakukan melalui pemasangan papan pengetahuan dan peraturan sekolah. MTs Khadijah mengupayakan penguatan kegiatan tersebut melalui pembiasaan dan contoh langsung dari guru.

\section{Pengontrolan}

Kegiatan pengontrolan dilakukan oleh semua pihak yang terlibat dalam pelaksanaan kegiatan PPK termasuk pembina. Terdapat penerapan buku pelanggaran yang berisi jenis pelanggaran, poin dan sanksi. Kegiatan pengontrolan juga dilakukan oleh BK melalui layananlayanan dasar dan khususnya.

SMPN 2 Kota Malang memiliki penambahan pada aspek pengontrolan yaitu memasang 64 CCTV dan pengadaan loker laporan yang disimpan di ruang guru sehingga semua pihak bisa menggunakannya untuk melaporkan apabila melihat pelanggaran, upaya ini dilakukan untuk melihat perilaku peserta didik di luar jangkauan, sedangkan MTs Khadijah hanya memasang dibeberapa tempat saja, dan memiliki buku rekapitulasi pribadi sebagai bukti saat orangtua ingin melihat perkembangan anaknya di sekolah. Hasil yang diperoleh pada beberapa instrumen pengontrolan yang digunakan akan dimasukkan sebagai nilai sikap peserta didik.

\section{Penguatan Pendidikan Karakter Peserta Didik}

\section{Gambar 2. Temuan Penelitian Lintas Kasus Manajemen Penguatan Pendidikan Karakter Peserta Didik di MTs Khadijah Malang dan SMPN 2 Kota Malang}

Berdasarkan pada hasil temuan lintas kasus pada gambar 4.45 di atas diperoleh hasil bahwa pengaktualisasian penguatan pendidikan karakter dilakukan secara terstruktur karena terlihat dengan adanya proses perencanaan terlebih dahulu sampai pada pengontrolan kegiatan, berikut penjelasan masing-masing proses: (1) perencanaan dilakukan setelah adanya usulan dari pihak internal, usulan harus memperhatikan nilai-nilai karakter yang akan ditampilkan pada kegiatan nantinya, setelah itu kemudian didiskusikan kembali untuk menentukan kegiatan yang tepat, sebelum membuat jadwal pelaksanaan kedua sekolah membentuk tim penanggungjawab untuk masing-masing kegiatan, kemudian kegiatan akan diberitahukan kepada orangtua peserta didik, kemudian merencanakan jadwal perbaikan kegiatan apabila dibutuhkan. (2) pelaksanaan PPK dilakukan pada semua aktifitas yang melibatkan peserta didik, seperti dalam kegiatan intrakurikuler, kokurikuler dan ekstrakurikuler, selain itu kedua sekolah sepakat bahwa penguatan juga dilaksanakan dalam kegiatan lainnya yang meliputi perilaku peserta didik saat memasuki gerbang sekolah, kelas dan kembali ke rumahnya. (3) pengontrolan dilakukan dengan menggunakan instrumen khusus yang kedua sekolah menggunakan buku pengontrolan yaitu buku tatib dan BKS, kemudian adanya pemasangan CCTV meskipun lebih banyak digunakan oleh SMPN 2 Malang karena sekolah ini dalam pengadaan sarana prasarananya dirangkum dalam RKA PPK khusus sarana prasarana untuk kemudian dijalankan dan diselesaikan oleh masing-masing pembina, kemudian adanya keterlibatan guru BK dalam memberikan layanan khusus sebagai bentuk pengontrolan secara manual sebelum buku tatib dan BKS ditulis, untuk SMPN 2 Malang yang membuatnya berbeda dengan MTs Khadijah adalah pada pengadaan loker laporan dan buku rekapitulasi yang dipegang dan ditulis langsung oleh kepala sekolah untuk melihat perkembangan peserta didik. Sebagai hasil evaluasinya maka jumlah pelanggaran yang dilakukan atau penilaian perilaku lainnya dimasukkan sebagai penialaian sikap pada rapor peserta didik.

\section{PEMBAHASAN}

Berdasarkan pada hasil temuan penelitian di lapangan, berikut peneliti kaitkan dengan teori-teori yang ada sebelumnya, sehingga memperkuat temuan penelitian, pembahasan berikut ini meliputi proses perencanaan, pelaksanaan, dan pengontrolan.

\section{Perencanaan Pengadaan Kegiatan PPK}

Perencanaan dilakukan oleh kedua sekolah sebagai langkah awal dalam menentukan kegiatan PPK dan proses itulah yang tampak dilakukan dalam hasil temuan penelitian, pernyataan ini membenarkan teori yang dipaparkan oleh Sobri (2019) bahwa proses perencanaan merupakan tindakan awal yang perlu diperhatikan oleh suatu organisasi dalam mencapai tujuan melalui kegiatan yang nantinya akan diterapkan. Kegiatan inilah yang nantinya direalisasikan sebagai perwujudan pelaksanaan 
hasil dari perencanaan seperti yang dipaparkan oleh (Taufiqurokhman, 2008) bahwasanya dalam proses perencanaan akan memunculkan serangkain tindakan yang selanjutnya akan direalisasikan. Pada proses perencanaan kedua sekolah sepakat untuk memilih jenis kegiatan yang tepat berdasarkan usulan yang diberikan, dan hasil temuan ini memperkuat teori yang disampaikan oleh (Slamet, 2017) bahwa di dalam proses perencanaan tentu akan menghasilkan banyak kegiatan, dan organisasi pelaksana mempunyai wewenang untuk memilih tindakan atau kegiatan yang tepat untuk memperkuat pendidikan karakter peserta didik. Usulan yang sebelumnya diberikan tentu mempertimbangkan keberadaan nilai-nilai karakter, hal ini sesuai dengan pendapat oleh (Banusu, 2019) yang menyebutkan bahwa proses perencanaan PPK harus mempertimbangkan keberadaan nilai-nilai karakter dalam segala aktivitasnya.

\section{Pelaksaaan Kegiatan PPK}

Pada proses pelaksanaannya kedua sekolah memiliki perbedaan, dimana MTs Khadijah tetap menambahkan nilai-nilai Islam dalam kegiatan yang dijalankan seperti memisahkan antara laki-laki dan perempuan, dalam artian menjaga jarak agar tidak terjadi pergaulan yang diluar ajaran Rasulullah Saw, temuan ini membuktikan teori yang dipaparkan oleh (Farida, 2016) bahwa sekolah yang berstatus Madrasah memiliki penambahan dalam karakter yang akan dibentuknya yaitu nilai Islam. Pelaksanaan PPK juga dilakukan pada kegiatan intrakurikuler yaitu dengan mengintegrasikan nilai-nilai karakter di dalam pembelajaran, kokurikuler berupa pengayaan dan ekstrakurikuler (Mislia, Mahmud, \& Manda, 2016), hasil ini sesuai dengan perwujuduan PPK yang tertuang dalam PP RI No.87 Tahun 2017 tentang PPK. Pengaktualisasian penguatan pendidikan karakter peserta didik melalui kegiatan yang diselenggarakan oleh kedua sekolah, merupakan hasil dari perencanaan yang telah dilakukan dan hal ini menunjukkan tingkat keberhasilan dari perencanaan, dan dalam kegiatan pelaksanaan PPK ini peserta didik tentu akan memperoleh pemahaman dan pengetahuan mengenai norma yang berlaku di Negara dan daerahnya (Isnaini, 2018). Berdasarkan pada hasil temuan kasus individu juga menjelaskan bahwa dalam pelaksaan penguatan karakter peserta didik juga terlibat kegiatan olah hati yang membentuk karakter positif lain, seperti jujur dan bertanggung jawab dan hal ini terlihat juga dalam beberapa kegiatan di sekolah (Jaya, 2013).

\section{Pengontrolan Kegiatan PPK}

Kegiatan pengontrolan dilakukan langsung oleh kepala sekolah, temuan ini membuktikan adanya teori yang dipaparkan oleh (Salim, 2019) bahwa sebagai pemimpin dalam satuan pendidikan, kepala sekolah memiliki tanggungjawab untuk melakukan pengontrolan semua aktifitas sekolah, termasuk didalamnya kegiatan penguatan pendidikan karakter. Kedua sekolah sepakat bahwa tujuan dari kegiatan pengontrolan atau pengawasan adalah untuk melihat perkembangan suatu kegiatan, dan kedua sekolah sepakat bahwa apabila dalam pengontrolan menemukan kendala maka tindakan yang diambil adalah merevisi dan memperbaiki kembali kegiatan tersebut agar ke depannya berjalan dengan baik dan efektif (Effendy, 2016). Hasil temuan mengenai proses evaluasi yang dijadikan sebagai proses akhir dari pengontrolan menguatkan teori yang dijelaskan oleh (Effendy, 2016) bahwa dalam melakukan evaluasi harus berorientasi pada proses, kriteria keberhasilan, asas manfaat dan objektif, dan beberapa langkah inilah yang dilakukan oleh kedua sekolah dalam mengevaluasi hasil akhir perilaku peserta didik, yang juga berlandaskan pada maksimum jumlah poin pelanggaran yang seharusnya tidak diperoleh peserta didik yang kemudian hal ini akan berperingaruh pada penilaian sikapnya selama menjadi bagian di sekolah tersebut.

\section{SIMPULAN}

Penelitian ini membahas mengenai proses manajemen dalam penguatan pendidikan karakter untuk peserta didik yang meliputi proses perencanaan, pelaksanaan, dan pengontrolan yang dilakukan oleh MTs Khadijah Malang dan SMPN 2 Kota Malang. Kedua sekolah sepakat bahwa dalam proses perencanaan akan lebih efektif bila pihak internal yang terlibat, keterlibatan orangtua dirasakan setelah jenis kegiatan sudah diperoleh. Sebelum perencanaan dilakukan harus ada usulan yang diberikan, usulan harus mempertimbangkan jenis karakter yang akan dibentuk dan diperkuat. Setelah usulan diterima oleh kepala sekolah kemudian didiskusikan untuk menentukan jenis kegiatan yang tepat, setelah semua dilakukan barulah dibentuk penanggungjawab dan tim pengembang yang meninjau kegiatan PPK di sekolah.

Terakhir adalah membuat jadwal lanjut untuk mengevaluasi dan memberikan perbaikan pada kegiatan yang dirasa kurang memberikan manfaat untuk semua. (2) Pelaksanaan kegiatan penguatan pendidikan karakter diintegrasikan dalam semua kegiatan di sekolah yang melibatkan peserta didik seperti pada saat memasuki gerbang sekolah, memasuki kelas, memulai pembelajaran dan mengakhirinya, kemudian juga termasuk dalam PPK terjadwal seperti intrakurikuler, kokurikuler, dan ekstrakurikuler. (3) Pengontrolan merupakan tindakan memantau perkembangan kegiatan yang dijalankan oleh sekolah, begitu pula yang terlihat dilakukan oleh MTs Khadijah Malang dan SMPN 2 Kota Malang, pengontrolan dilalukan menggunakan alat berupa CCTV, buku kontrol perkembangan perilaku peserta didik dan kreativitas kepala sekolah dalam mengadakan buku rekapitulasi untuk mengetahui peserta didik yang sering melakukan pelanggaran dan pengadaan loker pelaporan bagi semua pihak yang melihat adanya pelanggaran. 
Saran-saran yang dapat peneliti berikan berdasarkan pada temuan penelitian sebelumnya sebagai berikut. Pertama, Menteri Pendidikan Republik Indonesia perlu memperhatikan perkembangan pendidikan di setiap sekolah dan membentuk kerjasama salah satunya melalui pemberian anggaran untuk memenuhi pengadaan sarana prasarana yang menunjang perkembangan IMTAQ dan IPTEK peserta didik. Kedua, Dinas Pendidikan Kota Malang selaku pihak pemerintahan yang mengatur jalannya pendidikan di kota Malang haru terus berupaya untuk mempertahankan budaya dan lingkungan sekolah seperti yang terlihat pada SMPN 2 Malang yang menjadi salah satu pelaksana program PPK. Ketiga, Kementerian Keagamaan kota Malang juga diharapkan dapat memperhatikan perkembangan pendidikan salah satunya dilakukan oleh MTs Khadijah Malang, untuk selanjutnya dapat bekerjasama dalam mengadakan kebutuhan sekolah. Keempat, Kepala Sekolah MTs Khadijah dan SMPN 2 Malang ke depannya sangat peneliti harapkan bahwa dengan adanya tesis ini, dapat digunakan untuk mengevaluasi kembali pelaksanaan kegiatan penguatan pendidikan karakter peserta didik, meskipun peneliti mengetahui bahwa pelaksanaan penguatan karakter di sekolah ini sudah sangat baik. Kelima, bagi orangtua peserta didik untuk semua sekolah sangat peneliti harapkan kerjasama yang baik dalam membangun pendidikan yang cerdas, tepat dan dapat menjadikan anaknya memiliki kesiapan untuk menghadapi perkembangan zaman di tahun berikutnya.

\section{DAFTAR RUJUKAN}

Agung, L. (2018). Character Education Integration in Social Studies Learning. Historia: Jurnal Pendidik dan Peneliti Sejarah. 12(2), 392-403. https://doi.org/10.17509/historia.v12i2.12111

Banusu, F. (2019). Manajemen Penguatan Pendidikan Karakter Berbasis Spiritualitas (Studi Multi Situs di SDK Mardi Wiyata 1 dan SDK Indriyasana Malang. Tesis tidak diterbitkan. Universitas Negeri Malang, Malang.

Berkowitz, M. W., \& Bier, M. C. (2004). Research Based Character Education. Annals of the American Academy of Political and Social Science. https://doi.org/10.1177/0002716203260082

Bogdan, R. C., \& Bikien, S. K. (1998). Qualitative Research for Education. In Qualitative Research for Education: An Introduction to Theory and Methods.

Chusnani, D. (2013). Pendidikan Karakter Melalui Sains. Jurnal Kebijakan dan Pengembangan Pendidikan, 1(1), 9-13.

Creswell, J. W. (2016). Research Design: Pendekatan Metode Kualitatif, Kuantitatif, dan Campuran. SAGE Publication.

Dahliyana, A. (2017). Penguatan Pendidikan Karakter melalui Kegiatan Ekstrakurikuler di Sekolah. Jurnal Sosio Religi: Jurnal Kajian Pendidikan Umum, 15(1), 54-64.

Dalyono, B., \& Lestariningsih, E. D. (2017). Implementasi Penguatan Pendidikan Karakter di Sekolah. Bangun Rekaprima: Majalah Ilmiah Pengembangan Rekayasa, Sosial dan Humaniora, 3(2), 33-42.

Effendy, M. (2016). Konsep dan Pedoman Penguatan Pendidikan Karakter: Tingkat Sekolah Dasar dan Sekolah Menengah Pertama. Tim PPK Kemendikbud. Jakarta.

Fajarini, U. (2014). Peranan Kearifan Lokal Dalam Pendidikan Karakter. Sosio Didaktika: Social Science Education Journal, 1(2), 123-130. https://doi.org/10.15408/sd.v1i2.1225

Farida, S. (2016). Pendidikan Karakter dalam Perspektif Islam. Kabilah (Journal of Social Community), 1(1), $198-207$.

Imron A., Maisyaroh., \& Burhanuddin. (2003). Manajemen Pendidikan: Analisis Substantif dan Aplikasinya dalam Institusi Pendidikan. Malang: Universitas Negeri Malang.

Imron, A. (2015). Manajemen Peserta Didik Berbasis Sekolah Dasar. Jakarta: PT. Bumi Aksara.

Isnaini, R. L. (2016). Penguatan Pendidikan Karakter Siswa melalui Manajemen Bimbingan dan Konseling Islam. Manageria: Jurnal Manajemen Pendidikan Islam, 1(1), 35-52. https://doi.org/10.14421/manageria.2016.11-03

Jaya, H. (2013). Pengembangan Laboratorium Virtual untuk Kegiatan Paraktikum dan Memfasilitasi Pendidikan Karakter di SMK. Jurnal Pendidikan Vokasi, 2(1), 81-90. https://doi.org/10.21831/jpv.v2i1.1019

Judiani, S. (2010). Implementasi Pendidikan Karakter di Sekolah Dasar Melalui Penguatan Pelaksanaan Kurikulum. Jurnal Pendidikan dan Kebudayaan,16(9), 280-289. https://doi.org/10.24832/jpnk.v16i9.519

Krakowiak, K. M., \& Tsay-Vogel, M. (2013). What Makes Characters' Bad Behaviors Acceptable? The Effects of Character Motivation and Outcome on Perceptions, Character Liking, and Moral Disengagement. Mass Communication and Society. 16(2) https://doi.org/10.1080/15205436.2012.690926

Maksudin. (2013). Pendidikan Karakter Nondikotomik (Upaya Membangun Bangsa Indonesia Seutuhnya). Jurnal Pendidikan Karakter, 3(2), 137-152.

Mislia, M., Mahmud, A., \& Manda, D. (2016). The Implementation of Character Education through Scout Activities. 9(6). International Education Studies. https://doi.org/10.5539/ies.v9n6p130

Moleong, L. (2016). Metode Penelitian Kualitatif. Bandung: PT Remaja Rosdakarya.

Mulyasa, E. (2016). Manajemen Pendidikan Karakter. Jakarta: PT Bumi Aksara.

Mustoip, S., Japar, M., \& Zulela, M. (2018). Implementasi Pendidikan Karakter. Surabaya: CV. Jakad Publishing.

Nasihin, S. \& S. (2011). Manajemen Peserta Didik: Manajemen Pendidikan. Bandung: Alfabeta.

Salim, A. (2015). Manajemen Pendidikan Karakter di Madrasah (Sebuah Konsep dan Penerapannya). 2(1). ttps://www.neliti.com/publications/256501/manajemen-pendidikan-karakter-di-madrasah

Slamet, S. (2017). Implementasi Standar Manajemen Iso 9001:2015 Pada Lembaga Amil Zakat (Laz) Nasional (Studi Nu CareLazisnu). 1(1). Al-Idarah: Jurnal Manajemen dan Administrasi Islam. https://doi.org/10.22373/al-idarah.v1i1.1523 
Sobri, A. Y. (2017). Sekolah Dasar: Kajian Teori dan Praktik Pendidikan. Sekolah Dasar: Kajian Teori dan Praktik Pendidikan. 24(2).

Sonhadji, A., \& Huda, M. A. (2015). Asesmen Kebutuan, Pengambilan Keputusan, dan Perencanaan: Matarantai dalam Manajemen Pendidikan. Malang: Universitas Negeri Malang.

Sudrajat, A. (2011). Mengapa Pendidikan Karakter? . Jurnal Pendidikan Karakter, 1(1), 47-58.

Suharsimi, A. (2013). Prosedur Penelitian : Suatu Pendekatan Praktik. Jakarta: Rineka Cipta.

Sumarni, S., Dardiri, A., \& Zuchdi, D. (2015). Developing A Model of Social Capital Enforcement-Based Character Education for The Students of Sunan Kalijaga Islamic State University, 3(1). Jurnal Pembangunan Pendidikan: Fondasi dan Aplikasi, 3(1), 44-57. DOI: https://doi.org/10.21831/jppfa.v3i1.7811

Suparno. (2018). Analisis Faktor-Faktor Pembentuk Karakter Smart Siswa di Sekolah Islam Terpadu. Jurnal Pendidikan Karakter, 8(1), 62-73.

Suyadi. (2018). Strategi Pembelajaran Pendidikan Karakter. Bandung: PT Remaja Rosdakarya.

Taufiqurokhman. (2008). Konsep dan Kajian Ilmu Perencanaan. Jakarta: Fakultas Ilmu Sosial dan Ilmu Politik Universitas Prof. Dr. Moestopo Beragama.

Ulfatin, N. (2015). Metode Penelitian Kualitatif di Bidang Pendidikan: Teori dan Aplikasinya. Malang: Media Nusa Creative. 